MEGALOPTA SMITH, 1853 (INSECTA, HYMENOPTERA): PROPOSED DESIGNATION OF A TYPE-SPECIES UNDER THE PLENARY POWERS. Z.N.(S.) 1624

By Charles D. Michener (University of Kansas, Lawrence, Kansas, U.S.A.) and J. S. Moure, C.M.F. (University of Paraná, Curitiba, Brazil)

The purpose of the present application is to request the use of the plenary powers to designate a type-species for Megalopta Smith, 1853, in accordance with accustomed usage.

2. Megalopta Smith, 1853 (Catalogue hymenopt. Ins. Coll. Brit. Mus. 1 : 83) was described with two included species, bituberculata Smith, 1853, and idalia Smith, 1853. The genus has become well-known in the neotropical region and has never been attributed to any other area. There is a monograph of the genus by Friese (1926) and revisional or biological studies by Cockerell (1900), Ducke (1912), Schrottky (1902), Moure, $(1943,1958)$ and others.

3. Cockerell (1900, Proc. Acad. nat. Sci. Philad.) and Meade-Waldo (1916, Ann. Mag. nat. Hist. (8) $17: 451$ ) designated M. bituberculata as the typespecies. Unfortunately the type of $M$. bituberculata is actually an Australian insect in a different subfamily erroneously attributed to South America, as an examination of the type specimen in the British Museum (Natural History) shows. It would normally be placed in the Indoaustralian genus or subgenus Reepenia Friese, 1909 (Ann. Hist. Nat. Mus. Hungarici 7 : 205). Acceptance of the type designation would result in transfer of the name Megalopta from a Neotropical to an Australian group of bees and changes in the names of both groups.

4. Moure, 1958 (J.N.Y. ent. Soc. $66: 179)$ argued that, because most of the characters cited in the original description of Megalopta were based upon $M$. idalia, that form and not $M$. bituberculata ought to be the type-species of the genus. This is in accordance with the type designation of idalia by Ducke, 1912 (Zool. Jahrb., Syst. 34 : 85). Regardless of the validity of Moure's argument, it is obvious that to conserve the currently accepted generic nomenclature, the Commission should take the following steps:

(1) make use of its plenary powers to set aside all designations of typespecies for the nominal genus Megalopta Smith, 1853, and, having done so, designate Megalopta idalia Smith, 1853, to be the type-species of that genus;

(2) place the following generic names on the Official List of Generic Names in Zoology:

(a) Megalopta Smith, 1853 (gender : feminine), type-species, by designation under the plenary powers in (1) above, Megalopta idalia Smith, 1853; 


\section{Bulletin of Zoological Nomenclature}

(b) Reepenia Friese, 1909 (gender : feminine), type-species, by monotypy, Nomia variabilis Friese, 1909;

(3) place the following specific names on the Official List of Specific Names in Zoology: (a) idalia Smith, 1853, as published in the binomen Megalopta idalia
(type-species of Megalopta Smith, 1853);

(b) variabilis Friese, 1909, as published in the binomen Nomia variabilis (type-species of Reepenia Friese, 1909). 


\section{$2 \mathrm{BHL}$ Biodiversity Heritage Library}

Michener, C D and Moure, J S. 1964. "Megalopta , 1853 (Insecta, Hymenoptera): proposed designation of a type-species under the plenary powers. Z.N.(S.) 1624." The Bulletin of zoological nomenclature 21, 148-149. https://doi.org/10.5962/bhl.part.28479.

View This Item Online: $\underline{\text { https://www.biodiversitylibrary.org/item/44463 }}$

DOI: https://doi.org/10.5962/bhl.part.28479

Permalink: https://www.biodiversitylibrary.org/partpdf/28479

\section{Holding Institution}

Natural History Museum Library, London

\section{Sponsored by}

Natural History Museum Library, London

\section{Copyright \& Reuse}

Copyright Status: In copyright. Digitized with the permission of the rights holder.

License: http://creativecommons.org/licenses/by-nc-sa/3.0/

Rights: https://biodiversitylibrary.org/permissions

This document was created from content at the Biodiversity Heritage Library, the world's largest open access digital library for biodiversity literature and archives. Visit BHL at https://www.biodiversitylibrary.org. 